\title{
APPLICATION OF ONLINE DISPUTE RESOLUTION (ODR) IN INTERNATIONAL AND INDONESIA DOMAIN NAMES DISPUTES
}

\author{
Dheka Ermelia Putri
}

PT. Mitra Sejuk Selaras, Indonesia, Email: ermeliadheka@gmail.com

Submitted: January 4, 2019; Reviewed: January 29, 2019; Accepted: February 7, 2019

\begin{tabular}{ll}
\hline \multicolumn{1}{c}{ Article Info } & \multicolumn{1}{c}{ Abstract } \\
\hline Keywords: & The Online Dispute Resolution has become a \\
Online Dispute Resolution, Domain & breakthrough in the world of law, especially the law of \\
Names, Dispute Settlement. & dispute settlement. Online Dispute Resolution is used in \\
DOI: & several disputes such as e-commerce disputes and \\
10.25041/lajil.v1i1.2021 & domain name. Technically, part of the ODR has been \\
& used by Indonesia's Constitutional Court, where the \\
& Indonesian Constitutional Court utilizes video \\
& conferencing facilities in listening to witness testimonies \\
& and expert opinions. Moreover, PANDI (Pengelola Nama \\
& Domain Indonesia) has implemented most of the \\
& functions of the ODR in resolving Domain Name \\
& disputes in Indonesia like one of the cases that has been \\
& resolved, we call as "Netflix.id" Case that is the case of \\
& the Netflix Company who has used Netflix's name as \\
& merchandise since 1977. Netflix Company knowing that \\
& there is a new domain name that uses the name of the \\
& item, namely "Netflix.id" is officially registered and this \\
& interferes with the trading of the Netflix Company, with \\
& the result that Netflix Company filed a lawsuit to namely \\
& removing the "Netflix.id" domain name. This case was \\
& resolved without going through a face to face PPND \\
& Process (Pedoman Perselisihan Nama Domain) as a legal \\
& basis under Indonesian legislation Currently. Online \\
Dispute Resolution has been used by various world & organizations including UNCITRAL, European \\
Commission, and WIPO Arbitration and Mediation. & PANDI (Pengelola Nama Domain Internet Indonesia) as \\
& one of the parties that utilize the online dispute resolution \\
has policies established under existing international \\
regulations. Still, the ODR has been applied in some \\
cases and resulted in binding decisions to the parties.
\end{tabular}

\section{A. Introduction}

The development of internet technology has made an impact and also converted the existing cultures of dispute resolution's general ways because the conventional dispute settlements or resolutions are considered insufficient to fulfil the international society's requirements. The existence of a dispute resolution's institution or mechanisms usually has a purpose of creating the best way of how a dispute is solved by peace. If we are to review the previous dispute resolution, then the settlement would only be availably done face to face.

In progress, international subjects have come to a need of dispute resolution that is simpler, light 
cost, and saves time, which means a dispute resolution that does not obligate the parties to attend in another country's jurisdictions, or the form of online dispute resolution or usually known as Online Dispute Resolution. I Made Widnyana in his book stated that basically, Online Dispute Resolution is the same as the conventional dispute resolution, the difference is seen in its media, which uses the internet (International Network). According to I Made Widnyana, the Online Dispute Resolution has 3 (three) types of dispute settlement, which are negotiation, mediation, and arbitration. ${ }^{1}$ Online Prescription of Legal Action is a subsidiary of the Legal Action settlement that using technologies as facilities to solve the dispute between parties. ODR in this term, uses negotiation, mediation, or arbitration, or even a combination of all three.

Recently, the ODR is often used in national scope and international dispute of domain name. The domain name comes from an English term that is translated as nama domain in Bahasa, which means, a name in a region which is considered as an address in the internet world. Domain name dispute in Indonesia is still unfamiliar. Still, Indonesia already has a specific institution that occupies in dealing with domain name dispute that is known as Pengelola Nama Domain Internet Indonesia and will be preferred as PANDI.

One of the domain name dispute case in Indonesia resolved by PANDI is the dispute between Netflix, Inc v. Yulian Hariyanto. The object of this case is the "Netflix.id" domain name. The applicant is Netflix, Inc. put forward a lawsuit against Yulian Hariyanto because he had made and registered a domain name using the company's trademark, causing errors and losses for the company. Netflix, Inc. has used the trademark since 1977 and has obtained brand legal protection from its home country, the United States and they strongly existing to the enrollment of new domain titles that use their trademark rights. Eventually, Netflix, Inc., filed a lawsuit with the Respondent to delete the domain name. Netflix, Inc. cast a lawsuit through PANDI by using PPND as a legal basis. The process of resolving this case is via email only, without requiring a long time by using a mediation panel from the panellists registered at PANDI. The decision issued by PANDI is based on a treaty of mediation amongst the sides and the mediator on this matter, namely the removal of the domain titles "Netflix.id". This dispute is solved through ODR by sending objection files, attachment, and administrative notification to PANDI. Besides that, the parties also arranged mediation and responses through email, which the applicant eventually wins this case through the panellist judgment that stated the domain name "Netflix.id" is diverted to the applicant.

In this situation, ODR is categorized as a part of the Alternative Dispute Resolution (ADR). The difference lies where the ODR changes the traditional view into an innovative technique usage and only technology in its process. ${ }^{2}$ The idea of an ODR occurred can be searched when there are a transaction and interaction done online, which triggered the dispute in the ongoing transaction. ${ }^{3}$

ODR is usually used to solve the dispute of brand. The term brand here is not a merchandise brand, but it means as such in web address or domain. The domain name is a unique name that represents an organization in which that name would be used by internet users to connect with that particular organization. A domain name that has become an identity on a server in the internet world must be officially registered under the existing regulation. The allocation of an international domain name is under the authority of the Internet Corporation for Assigned Named and Number (ICANN), a mal benefit institution domiciled in California, United States. ${ }^{4}$ The policy of ICANN is leading as UniformDomain Name Dispute Resolution Policy (UDRP) which is an actual ${ }^{5}$ and adjective ${ }^{6}$ rule used by various parties in dealing with the issue of domain name ownership dispute in the form of

\footnotetext{
${ }^{1}$ I Made Widnyana, Alternatif Penyelesaian Sengketa and Arbitrase (Jakarta: Fikahati Aneska, 2014), 47.

${ }^{2}$ Felikas Petrauskas and Egle Kbartiene, Online Dispute Resolution in Consumer Disputes (Mykolas Romeris University: Jurisprudencia, 2011), 2. Contained in Gagah Satria Utama, "ONLINE DISPUTE RESOLUTION: A REVOLUTION IN MODERN LAW PRACTICE”, Business Law Review 3, no. 2 (2015): 1-6, 2, DOI: 10.1016/j.icj.2015.10.006. 3 Adel Chandra, "PENYELESAIAN SENGKETA TRANSAKSI ELEKTRONIK MELALUI ONLINE DISPUTE RESOLUTION (ODR) KAITAN DENGAN UU INFORMASI AND TRANSAKSI ELEKTRONIK NO.11 TAHUN 2008”, Jurnal Ilmu Komputer 10, no. 2 (2014): 80-89, 82, DOI: 10.20473/mi.v2i2.13912.

${ }^{4}$ Patricia L. Bellia, Cyberlaw Problems of Policy and Jurisprudence in the Information Age (St. Paul-MN: West, 2011), 266.

${ }^{5}$ The Substantive Rule is a written benchmark or measure as a guideline that regulates rights and obligations so that it is subject to a specific regulation (UDRP).

${ }^{6}$ The Adjective rule is a standart or measure that gives clear clues as to how substantive rules are enforced (The Rules).
} 
cyber court. ${ }^{7}$

In Indonesia, PANDI was established on December 29, 2006, as a non-profit organization which is specifically given authority by the Ministry of Communication and Informatics of the Republic of Indonesia by the Decree No. 806 Year 2014. The main purpose of ICANN and PANDI's establishment are to be a third party that would handle the domain name dispute in every country or between them. Based on the review above, the author has come to an interest to discuss the application of Online Dispute Resolution (ODR) in the international domain name dispute settlement. Based on the background description above, the main problems that would be discussed in this research are how is the mechanism of Online Dispute Resolution through UNCITRAL, European Commission and WIPO Arbitration and Mediation? And how is the application of Online Dispute Resolution towards the domain name dispute settlement in Indonesia?

This research method uses juridical empirical legal research with descriptive research type. Juridical empirical method is carried out to research in reality or based on objective facts in the field. ${ }^{8}$ The data collection is through literature study and document study with additional data of interview result. The data preparation was finished by data preference, data examination, data allocation and data preparation. Data analysis was done descriptively for qualitative data.

\section{B. Discussion}

\section{International Online Dispute Resolution}

\section{a) UNCITRAL}

The United Nations Commission on International Trade Law, or better known as UNCITRAL, was formed from the UN Generic Council with Prescript 2205 (XXI) on December 17, 1966, which plays a notable part in evolving a framework that continues the advanced confirmation and modernization of transnational commerce policy with organizing and encouraging the use and levitation of legislative and non-legislative appliance in the amount of key region of commercial law. These regions contain Prescription of Legal Action, international contract practices, secure transactions, procurement and sale of goods. ${ }^{9}$

Online dispute resolution through UNCITRAL is submitted to Working Group III, which is intended to discuss more Online Dispute Resolution. As a legal entity using the online dispute resolution process, UNCITRAL in collaboration with Working Group III established a legal record called Technical Records on Online Dispute Resolution. In Section III of Technical Records on Online Dispute Resolution describes the ODR poses stages consisting of stages including negotiations, facilitated dispute resolution and final stages. The stages of Online Dispute Resolution through UNCITRAL can be summarized as:

1) The applicant filed a notice through the ODR platform ${ }^{10}$ http://pemohon.uncitral.org/uncitral/contact_us.html to the ODR organizer.

2) Afterwards, the ODR organizer would inform the pleated about the existing claims and applicant by email.

3) After receiving a response ${ }^{11}$ from the pleated in the first stage, then a negotiation would be

\footnotetext{
${ }^{7}$ Meliala and Jordan Sebastian, "PERLINDUNGAN NAMA DOMAIN DARI TINDAKAN PENDAFTARAN NAMA DOMAIN DENGAN ITIKAD BURUK BERDASARKAN HUKUM POSITIF INDONESIA DAN UNIFORM DOMAIN NAME DISPUTE RESOLUTION POLICY," Kumpulan Jurnal Mahasiswa Fakultas Hukum 4, no. 2 (2015): $1-18,8$.

8 Andriawan Kusuma et al., "GANTI RUGI TANAH SISA PADA PEMBANGUNAN JALAN TOL BAKAUHENITERBANGGI BESAR; AKIBAT HUKUM DAN KONFLIK PERTANAHAN (COMPENSATION FOR REMAINING LAND IN THE CONSTRUCTION OF THE BAKAUHENI-TERBANGGI BESAR TOLL ROAD; DUE TO LAWS AND LAND CONFLICTS)," Cepalo 3, no. 1 (2019): 41-54, 43, DOI: 10.25041/cepalo.v3no1.1785.

${ }^{9}$ UNCITRAL. (n.d). A Guide to UNCITRAL : Basic Facts About the United Nations Commission on Internasional Trade Law (Vienna, Austria: UNCITRAL Secretariat, 2013), 1

10 The contents of the notice of the applicant are: the applicant's name and electronic address and the applicant's representative authorized to act for the applicant in the ODR process, the Applicant's electronic name and location of the applicant's claim, the claiming basis, the Solution submitted for settlement of the dispute, to be used by the applicant, signature or identification and authentic means of the applicant or his representative, along with reliable documents.

${ }^{11}$ The responses of the requested Party are: the respondent's name and electronic address and the representative acting on behalf of the requested party, the response to the claim-making basis, the proposed Sequence to settle disputes, signatures
} 
arranged, where the applicant and the pleated would directly negotiate with each other, but done through a technology system or a platform (email).

4) If the negotiation fails, it would be continued but arranging a settlement through a resolution facility, where the ODR administrator appoints a neutral party that will communicate through a platform with the disputed parties in order to have a solution.

5) If the facilitated settlement method fails, it can be followed up by the third or final stage, whereby the ODR Administrator or the neutral party shall explain the nature or technical nature of the final stage of the dispute resolution to the parties. ${ }^{12}$

There is one minor of the Technical Records on Online Dispute Resolution that the content fails to mention the estimation of expenses that would be necessary for this online resolution process.

\section{b) European Commission}

The European Commission (EC) is an institution in the EU that is not related to EU member states. When compared to the existing authorities within a country, the EC is an executive body. In its tenure, the European Commission is accountable to the European Parliament.

On February 15 2016, the European Commission set up an Online Dispute Resolution (ODR) portal for utilize by users residing in the European Union. ODR is an instrument supplied by the European Commission to assist EU consumers in settling disputes outside the court.

ODR through the European Commission is conducted using a website based platform. The goal is to assist users and merchants settle users' contract legal action regard to purchasing stuff and merits online out of judiciary at a modest expense in a usual and rapid method. This enables users to file an online legal action in one of 23 appointed languages of the European Union. This ODR platform only leads legal action to the prescription of legal action agencies delivered by fellow nations.

Online Dispute Resolution through the European Commission is regulated in Regulation (EU) No 524/2013 Of The European Parliament And Of The Council of May 21, 2013, on the online prescription of legal action for user disputes and altering Ordinance (EC) No 2006/2004 and Directive 2009/22/EC (Regulation on consumer ODR) and Commission Execute Regulation (EU) 2015/1051 of July 1, 2015, on the modalities for the practice of the purpose of the online prescription of legal action platform, on the modalities of the electronic plaint form and on the modalities of the collaboration amongst contact points supplied for in Ordinance (EU) No 524/2013 of the European Parliament and of the Council on the online prescription of legal action for user disputes.

The Committee on Executing Ordinance (EU), 2015/1015 of July 1, 2015, describes the ODP process consisting of stages including registration, negotiation to the final stages. The stages of Online Prescription of Legal Action through the European Commission can be summarized as:

1) The applicant must sign in (if owned an account) or register through the site. ${ }^{13}$

2) Afterwards, the applicant decides if one is a consumer or a trader.

3) After signing in, the applicant submits an electronic complaint form filed through the ODR platform. The complaining party should be capable of keeping a concept of an electronic plaint form on the ODR platform. The concept must be obtainable and editable by the complaining party before submitting the completed electronic complaint forms. The unfinished and submitted electronic complaint form design will be removed from the ODR platform six months since its formation. ${ }^{14}$

4) After the system ensures that the electronic complaint forms are appropriate and complete, the ODR platform must send a basic electronic order to the party's electronic address represented by the complainant in the electronic complaint form, notifying that a plaint was filed toward it and providing such explanation. ${ }^{15}$

5) ADR complaints that have been submitted through the ODR platform and have been approved and signed without any delay after receiving a fulfilling plant archive relating to the dispute submitting to the ODR platform on approval of the fulfil application archives as well as the

or means of identification and authentic as the liability of the requested and /or representative, of any replies that contain the reasons, along with reliable documents.

${ }^{12}$ UNCITRAL, Technical Notes on Online Dispute Resolution, (Vienna, Austria: UNCITRAL Secretariat, 2017), 17.

${ }^{13} \mathrm{https}: / /$ cc.europa.eu/consumers/odr/main/index.cfm?event=main.home.show\&lng=EN, Accessed on March 2, 2017.

${ }^{14}$ Article 2 Commission Implementing Regulation (EU) 2015/1051 of 1 July 2015.

${ }^{15}$ Article 3 Commission Implementing Regulation (EU) 2015/1051 of 1 July 2015. 
fundamental bodies of the law action. The date of approval of the fulfil application archives started on a 90 calendar day era. When a plant was sent thru the ODR platform, and one of the parties refuses to face a dispute, the refusing party must submit a rejection to the ODR platform without delaying the decision. Respondent sends a response from complaints that have been sent.

6) When a complaint has been sent, and both parties agree, then both parties should select the desired dispute resolution body in the site https://ec.europa.eu/consumers/odr/main/index.cfm? event $=$ main. adr.show with an estimated time of 30 working days.

7) Details of complaints and responses are sent to the selected Dispute Resolution body.

8) The dispute resolution body has 21 working days to decide whether the agency is competent or does not handle the dispute.

9) Afterwards, the results and the closing of the application would be decided by resolution agency and shall be handed over both parties. When a plaint was dispatched via the ODR platform, thereout any postpone at the end of the law action, on a certain date a conclusion of the ADR procedure and outcome will be included when one or both parties withdraws from the ADR procedure. ${ }^{16}$

Article 6 of the Committee Executing Ordinance (EU) 2015/1051 of July 120 explains that there are several criteria for how the law action handed over the ODR platform will not be cultivated:

1) The requested Party declares that they do not want to use ADR entity;

2) The parties do not approve the ADR body to handle parties' disputes until 30 calendar days toward the submission of the electronic plaint forms;

3) The ADR body acquiescent upon by the sides resist to handle such disputes and is deemed to be completed. Upon deletion of an existing dispute, the previously uploaded personal data will be automatically eliminated by the ODR platform no later than six months since their conclusion. ${ }^{17}$ Online Dispute Resolution through UNCITRAL and the European Commission is an overview of ODR use in the world. When entering the domain of a specific dispute like a "domain name" dispute, the dispute can not be resolved through UNCITRAL or the European Commission, but can be resolved through WIPO Arbitration and Mediation internationally and PANDI in the national sphere, especially Indonesia.

\section{c) WIPO Arbitration and Mediation}

WIPO Arbitration and Mediation were founded in 1994 based in Geneva, Switzerland and has a branch office in Maxwell Chambers, Singapore. WIPO Arbitration and Mediation is part of the World Intellectual Property Organization (WIPO) under the Patents and Technology sector and is under the leadership of DDG John Sandage. ${ }^{18}$ WIPO Arbitration and Mediation is an international resource as an alternative to timely and cost-effective dispute settlement that provides more than 1.500 neutral parties that will assist the parties in solving their problems directly or online.

WIPO is an international leader in the stipulation of "domain name" prescription of legal action services have a basis on UDRP to be designed by WIPO and adopted by the international "domain name" organization ICANN. ${ }^{19}$ According to UDRP, three important elements become the category of a "domain name" dispute can be said of a "domain name" dispute, namely: ${ }^{20}$

1) The domain title is common or alike to another trade name or brand confusing.

2) A person hasn't legitimate rightness or fascinates in connection with "domain title".

3) The domain title that was recorded, and then there is someone who uses it with bad intentions.

Below is the "domain name" dispute settlement process through WIPO Arbitration and Mediation tailored to The Regulation for Uniform Domain Title Prescription of Legal Action Policy:

1) The applicant filed a complaint: Complaints may be filed through the website and email. Completion of complaint form through the website. ${ }^{21}$ Complaints given to officers should not be

\footnotetext{
${ }^{16}$ Article 5 No. 1 Commission Implementing Regulation (EU) 2015/1051 of 1 July 2015.

${ }^{17}$ Article 6 No. 2 Commission Implementing Regulation (EU) 2015/1051 of 1 July 2015.

${ }^{18}$ Activities by Unit. Available in http://pemohon.wipo.int/about-wipo/en/activities_by_unit/, Accessed on November 10, 2017.

${ }^{19}$ Available in http://pemohon.wipo.int/amc/en/, Accessed on November 10, 2017.

${ }^{20}$ ICANN. Uniform Domain-Name Dispute Resolution Policy: Article 4 Paragraph A.

${ }^{21}$ It is can be filled in https://www3.wipo.int/amc- forms/en/udrp/eudrpcomplaint.jsp or the applicant would like to file a complaint via email, the bias complaint form is obtained on http://page applicant.wipo.int/amc/en/domains/complainant
} 
given to the requested party.

2) Verify the Registrar: After the complaint is filed, the provider must request the registrar's verification, which includes a request to lock the "domain name" in question. This is done so that "domain name" will not be transferred to other registrants during the UDRP process.

3) Delivery of application to the requested party: After the provider sends the requests to the requested party, the administrative process begins. ${ }^{22}$

4) The Respondent submits a response: Within 20 working days of the administrative process, the applicant submits a response to the organizer and requests four additional calendar days. Response ${ }^{23}$ submitted including attachments must be submitted electronically. ${ }^{24}$

5) Panel selection: Both parties make a panel selection, whether to use one panel or three panels listed in the provider's list. If the parties do not choose a panellist, the provider will choose a panellist that will be fully paid by the applicant. If the applicant or the requested person chooses had a legal action determined by the three-fellows panel, the people who provide would designate three panellists in conformity with the existing procedure.

6) Collection of all evidence files: When panellists have been selected, all files related to the dispute will be sent to each panel. ${ }^{25}$

Panellist verdict: After the submission of all the evidence, the panellists shall counsel and decide in writing and based on the existing documents and according to the policy. If it consists of 3 panellists, then the decision is made with a majority vote. ${ }^{26}$ The verdict made is binding because only the ICANN and WIPO can lock or divert the "domain name" in question. Payment: Payment is made to the WIPO Centre which will be distributed to the respective panellists.

\section{Application Online Dispute Resolution in Indonesia}

\section{a) Pengelola Nama Domain Internet Indonesia (PANDI)}

PANDI formed by a community and appointed by the government through the Ministry of Communications and Information Technology which is responsible for managing all "domain name" internet in Indonesia other than go.id and mil.id which contained in the submission of news report "domain name" .id no. BA-343 / DJAT / MKOMINFO / 6/2007 from the Director-General of Aptel to PANDI on December 26 2006. PANDI as the board of "domain name" Indonesia is directly under the "domain name" forum below a leadership of the Ministry of Communication and Information.

Domain Name Dispute Settlement Policy, this policy is sourced from ICANN and WIPO UDRP. ${ }^{27}$ Completion of domain name disputes through PANDI, is transferred to a special agency that is Penyelesaian Perselisihan Nama Domain or PPND is a non-litigation dispute settlement for rights of "domain name" disputes, namely "brand name" disputes, "domain name" dispute related to registered names and "domain name" dispute related to propriety prevailing in the community. ${ }^{28}$

1) Settlement of disputes through PPND is described in detail and in detail in the Domain Title Dispute Settlement Policies. Still, in the Domain Title Dispute Settlement Guideline, the case flow through PPND is explained briefly, concise and clear, in which the channels described include: Appeals and Panelist's suggestion: the applicant filed an objection and submitted a panellist proposal to the secretariat of PPND via email. The day of receipt of the applicant's objection file and declared complete by the PPND secretariat shall be counted as the effective

\footnotetext{
22 UDRP Model Complaint and Filling Guidelines. Available inhttp://pemohon.wipo.int/amc/en/domains/complainant/, Accessed on November10, 2017.

${ }^{23}$ Ibid. Point f.

${ }^{24}$ Responses consist of Responding specifically to the statements and allegations contained in the application and entering any and all bases for the requested ("domain name" holders) to maintain the registration and use of disputed "domain names", names, postal addresses and e- mail addresses, telephone and telefax number of the requested ("domain name" holder) and authorized representative acting for the requested party in the administration process, communication method, number of panels.

${ }^{25}$ Section 5 point a and $\mathrm{f}$ Rules for Uniform Domain Name Dispute Resolution Policy (The Rules)

${ }^{26}$ Ibid., Section 9.

${ }^{27}$ Ibid., Section 15.

${ }^{28}$ PANDI, Kebijakan Penyelesaian Perselisihan Nama Domain (Tanggerang: Pengelola Nama Domain Internet Indonesia, 2017), 1 .
} 
date of commencement of the PPND administration process. ${ }^{29}$

2) Payment of court fee: the applicant shall pay a case fee no later than 5 (five) days after the effective date by bank transfer.

3) Submission of the objection file to the requested Party: the PPND secretariat submits the complainant's objection file to the applicant and the relevant registrar via email five days after receipt of payment from the applicant.

4) Mediation: The PPND Secretariat gives time for the possibility of holding a 21-day mediation pending response process from the requested party.

5) Submission of responses and panellist suggestions: the Respondent would submit the respond and panellist suggestion in 21 days after receiving the applicant's objection file.

6) Payment of additional fee: the applicant pays an additional court fee when proposing the addition of the panellist number for 21 days after receiving the applicant's objection file.

7) Establishment and approval of panellists: the PPND secretariat establishes the panellist's composition in 5 days after the objection and complete response is received by the PPND secretariat or in 5 days after the deadline of the response of the requested party has expired.

8) Verdict: the panellist shall render the verdict on the examination conducted after the 21 st day of examination of the case upon receipt of all file completeness and response by email.

9) Establishment of Decision Letter: PANDI shall make a Decree of verdict in 1 (one) day after the decision is forwarded to the applicant, requested party and related registrar.

10) Announcement on the website: the PPND secretariat announces a panelist ruling through the PANDI website in 7 days after the publication of the decision.

11) Entry into force of the verdict: the registrar performs the content of the decision in 21 days after the decree is issued. The Registrar may cancel, assign or change the registration information of "domain name".

Within 21 days after the issuance of the PPND panellist ruling, the applicant and the applicant may file their lawsuit to the court and provide a copy of the registration of the case to the PPND secretariat. The secretariat of the PPND is subject to the outcome of a permanent legal court decision.

\section{Conclusions}

Online Dispute Resolution has been implemented by several international organizations, such as UNCITRAL, European Commission, WIPO Arbitration and Mediation and PANDI. Each organization has its guidelines for implementing ODR. However, these guidelines remain sourced from ICANN UDRP and The Rules. The object resolved by the European Commission and UNCITRAL is different from WIPO Arbitration and Mediation and PANDI. WIPO Arbitration and Mediation and PANDI, have their object of dispute, which is only to dispute domain names.

Application of Online Prescription of Legal Action in settlement of "domain title" legal action through PPND PANDI is almost entirely the same as WIPO Arbitration and Mediation since both use UDRP and The Rules WIPO. Both of the procedures of law look the same unless if it completes through PPND PANDI, it can not fill the form directly in a website as applied by WIPO Arbitration and Mediation. Payments received by PPND PANDI are only available via bank transfer, while WIPO Arbitration and Mediation can accept payment by credit card. ODR through WIPO Arbitration and Mediation and PPND PANDI comply with international regulations which are UDRP and The Rules WIPO. Decisions made by WIPO and PPND PANDI are both bindings on the parties, the difference of PPND PANDI decision can be appealed through the local court because PANDI is subject to the court of Indonesia.

\section{A. Journal}

\section{References}

Chandra, Adel. "PENYELESAIAN SENGKETA TRANSAKSI ELEKTRONIK MELALUI ONLINE DISPUTE RESOLUTION (ODR) KAITAN DENGAN UU INFORMASI AND TRANSAKSI ELEKTRONIK NO.11 TAHUN 2008”. Jurnal Ilmu Komputer 10, no. 2, 2014 : 80-89, DOI: $10.20473 / \mathrm{mi} . v 2 \mathrm{i} 2.13912$.

\footnotetext{
${ }^{29}$ PANDI, Panduan Penyelesaian Perselisihan Nama Domain (PPND), (Tanggerang: Pengelola Nama Domain Internet
} Indonesia, 2017), 3. 
Kusuma, Andriawan et al., "GANTI RUGI TANAH SISA PADA PEMBANGUNAN JALAN TOL BAKAUHENI-TERBANGGI BESAR; AKIBAT HUKUM DAN KONFLIK PERTANAHAN (COMPENSATION FOR REMAINING LAND IN THE CONSTRUCTION OF THE BAKAUHENI-TERBANGGI BESAR TOLL ROAD; DUE TO LAWS AND LAND CONFLICTS)," Cepalo 3, no. 1, 2019: 41-54, DOI: 10.25041/cepalo.v3no1.1785.

Meliala., Sebastian, Jordan. "PERLINDUNGAN NAMA DOMAIN DARI TINDAKAN PENDAFTARAN NAMA DOMAIN DENGAN ITIKAD BURUK BERDASARKAN HUKUM POSITIF INDONESIA DAN UNIFORM DOMAIN NAME DISPUTE RESOLUTION POLICY”, Kumpulan Jurnal Mahasiswa Fakultas Hukum 4, no. 2, 2015: 1-18.

\section{B. Book}

Adolf, Huala. Hukum Penyelesaian Sengketa Internasional. Jakarta: Sinar Grafika, 2014.

Bellia, Patricia L. Cyberlaw Problems of Policy and Jurisprudence in the Information Age. St. PaulMN: West, 2011.

Muhammad, Abdulkadir. Hukum dan Penelitian Hukum. Bandung: Citra Aditya Bakti, 2004.

PANDI, Kebijakan Penyelesaian Perselisihan Nama Domain. Tanggerang: Pengelola Nama Domain Internet Indonesia, 2017.

PANDI, Panduan Penyelesaian Perselisihan Nama Domain (PPND). Tanggerang: Pengelola Nama Domain Internet Indonesia, 2017.

Ramlan. Perkembangan Alternative Dispute Resolution (ADR) di Indonesia dan beberapa negara di dunia. Medan: Ratu Jaya, 2009.

Soejono., Abdurahman, H. Metode Penelitian Hukum. Jakart: Rineka Cipta, 2003.

Soekanto, Soejono., Mamudji, Sri. Penelitian Hukum Normatif: Suatu Tinjauan Singkat. Jakarta: Rajawali Pers, 1985.

Soekanto, Soejono., Mamudji, Sri. Penelitian Hukum Normatif: Suatu Tinjauan Singkat. Jakarta: Raja Grafindo Persada, 2003.

UNCITRAL, Technical Notes on Online Dispute Resolution. Vienna, Austria: UNCITRAL Secretariat, 2017.

UNCITRAL. (n.d). A Guide to UNCITRAL: Basic Facts About the United Nations Commission on Internasional Trade Law. Vienna, Austria: UNCITRAL Secretariat, 2013.

Utama, Gagah Satria. (n.d). "Online Dispute Resolution: A Revolution in Modern Law Practice". Business Law Review 3.

Widnyana, I Made. Alternatif Penyelesaian Sengketa dan Arbitrase. Jakarta: Fikahati Aneska, 2014.

\section{Regulation}

Commission Implementing Regulation (EU) 2015/1051 of July 1, 2015, ICANN: Uniform Domain Name Dispute Resolution Policy.

ICANN: The Rules for Uniform Domain Name Dispute Resolution Policy.

\section{Internet}

http://www.wipo.int/about- wipo/en/activities_by_unit/, Accessed on November 10, 2017.

http://www.wipo.int/amc/en/, Accessed on November 10, 2017.

http://www.wipo.int/amc/en/domains/complainant/, Accessed on November 10, 2017. 